\title{
Article \\ Somatic Mutations in Circulating Cell-Free DNA and Risk for Hepatocellular Carcinoma in Hispanics
}

\author{
Jingjing Jiao ${ }^{1}$, Jessica I. Sanchez ${ }^{1}$, Erika J. Thompson ${ }^{2}$, Xizeng Mao ${ }^{3}$, Joseph B. McCormick ${ }^{4}$, \\ Susan P. Fisher-Hoch ${ }^{4}$, P. Andrew Futreal ${ }^{3}$, Jianhua Zhang ${ }^{3}$ and Laura Beretta $1, *$ (D) \\ 1 Department of Molecular and Cellular Oncology, The University of Texas MD Anderson Cancer Center, \\ Houston, TX 77030, USA; jingjing099@gmail.com (J.J.); jisanchez@mdanderson.org (J.I.S.) \\ 2 Department of Genetics, The University of Texas MD Anderson Cancer Center, Houston, TX 77030, USA; \\ ejthomps@mdanderson.org \\ 3 Department of Genomic Medicine, The University of Texas MD Anderson Cancer Center, \\ Houston, TX 77030, USA; xmao1@mdanderson.org (X.M.); afutreal@mdanderson.org (P.A.F.); \\ jzhang22@mdanderson.org (J.Z.) \\ 4 Brownsville Regional Campus, School of Public Health, The University of Texas Health Science Center at \\ Houston, Brownsville, TX 78520, USA; joseph.b.mccormick@uth.tmc.edu (J.B.M.); \\ susan.p.fisher-hoch@uth.tmc.edu (S.P.F.-H.) \\ * Correspondence: lberetta@mdanderson.org; Tel.: +1-713-792-9100
}

check for updates

Citation: Jiao, J.; Sanchez, J.I.; Thompson, E.J.; Mao, X.; McCormick, J.B.; Fisher-Hoch, S.P.; Futreal, P.A.; Zhang, J.; Beretta, L. Somatic Mutations in Circulating Cell-Free DNA and Risk for Hepatocellular Carcinoma in Hispanics. Int. J. Mol. Sci. 2021, 22, 7411. https:// doi.org/10.3390/ijms22147411

Academic Editor: Robert Y. Tsai

Received: 9 June 2021

Accepted: 7 July 2021

Published: 10 July 2021

Publisher's Note: MDPI stays neutral with regard to jurisdictional claims in published maps and institutional affiliations.

Copyright: (c) 2021 by the authors. Licensee MDPI, Basel, Switzerland. This article is an open access article distributed under the terms and conditions of the Creative Commons Attribution (CC BY) license (https:/ / creativecommons.org/licenses/by/ $4.0 /)$.
Abstract: Hispanics are disproportionally affected by liver fibrosis and hepatocellular carcinoma (HCC). Advanced liver fibrosis is a major risk factor for HCC development. We aimed at identifying somatic mutations in plasma cell-free DNA (cfDNA) of Hispanics with HCC and Hispanics with advanced liver fibrosis but no HCC. Targeted sequencing of over 262 cancer-associated genes identified nonsynonymous mutations in 22 of the 27 HCC patients. Mutations were detected in known HCC-associated genes (e.g., CTNNB1, TP53, NFE2L2, and ARID1A). No difference in cfDNA concentrations was observed between patients with mutations and those without detectable mutations. HCC patients with higher cfDNA concentrations or higher number of mutations had a shorter overall survival $(p<0.001$ and $p=0.045)$. Nonsynonymous mutations were also identified in 17 of the 51 subjects with advanced liver fibrosis. KMT2C was the most commonly mutated gene. Nine genes were mutated in both subjects with advanced fibrosis and HCC patients. Again, no significant difference in cfDNA concentrations was observed between subjects with mutations and those without detectable mutations. Furthermore, higher cfDNA concentrations and higher number of mutations correlated with a death outcome in subjects with advanced fibrosis. In conclusion, cfDNA features are promising non-invasive markers for HCC risk prediction and overall survival.

Keywords: hepatobiliary diseases; disease prevention; health disparities; precision medicine

\section{Introduction}

The incidence of HCC has nearly tripled in the United States in the past 30 years and continues to rise, faster than for any other cancer in both men and women [1-3]. HCC has a dismal prognosis. It has the second lowest 5 -year survival $(18 \%)$, after pancreatic cancer [1]. This is largely due to the fact that the majority of HCC cases are diagnosed at an advanced stage when curative treatment options are limited [3,4]. Indeed, 5-year survival can reach $\sim 70 \%$ for early-stage HCC patients who undergo curative therapy $[5,6]$. Thus, detection of early-stage HCC is a major necessary step in improving overall survival. Over $90 \%$ of HCC develop on a liver with advanced fibrosis, cirrhosis in particular [7], and patients with cirrhosis are the targeted population for screening. Ultrasound and alpha-fetoprotein (AFP), the most broadly used modalities for HCC surveillance in patients with cirrhosis, lack sensitivity and specificity [8]. Novel modalities for HCC early detection are urgently needed, particularly in high-risk populations. Hispanics in South Texas have the highest age-adjusted incidence of HCC in the United States [9]. We also showed that 
this population has a 4 -fold higher prevalence of advanced liver fibrosis and cirrhosis than the general US population, primarily attributable to metabolic disease [10,11].

Cell-free DNA (cfDNA), present in plasma or serum samples, is thought to be derived from apoptotic cells as well as cellular secretion [12,13]. More importantly, cfDNA provides a comprehensive view of the tumor genome [14] and has offered unique opportunities as biomarkers for cancer prognosis [15], patient stratification for targeted therapy [16], and treatment monitoring [17-19]. Detection of somatic mutations in cfDNA at early tumor stages, including in asymptomatic subjects, have also been reported [20-24]. We reported the detection in cfDNA of TP53R249S mutation, a mutation in HCC associated with exposure to aflatoxin [25-28]. We detected this mutation in cfDNA samples from $5.7 \%$ of South Texas Hispanic patients with HCC [29]. We also reported the frequency of TERT promoter mutations, the most frequent genetic alteration in HCC [30-32], in cfDNA from HCC and cirrhotic patients [33]. Both studies demonstrated that some HCC somatic mutations can be detected in cfDNA of patients with liver cirrhosis, therefore confirming their potential utility in HCC risk assessment and early detection. In this study, we characterized the somatic mutations in cfDNA from South Texas Hispanic patients with HCC and determined whether some of these mutations can be detected in cfDNA from subjects from the South Texas population with advanced liver fibrosis or cirrhosis.

\section{Results}

\subsection{Somatic Mutations in cfDNA from Hispanic Patients with HCC}

We performed targeted sequencing of over 262 cancer-associated genes using the MD Anderson custom T200.1 platform, on cfDNA from plasma and genomic DNA from buffy coat, collected from 27 Hispanic patients with HCC. The clinical and demographic parameters of these patients are summarized in Supplementary Table S1. The majority of these patients were male $(66.7 \%)$, with a median age of 68 . The prevalence of obesity and diabetes among these patients was high, at $40 \%$ and $74.1 \%$, respectively. Approximately a third of these HCCs were in stages I or II. cfDNA concentrations ranged from 0.045 to $0.71 \mathrm{ng} / \mathrm{uL}$, with a median concentration of $0.18 \mathrm{ng} / \mathrm{uL}$. Spearman correlation analysis showed that among all available clinical parameters, cfDNA concentrations only positively correlated with tumor stage $\left(\mathrm{r}_{\mathrm{s}}=0.48, p=0.012\right)$ (Figure $\left.1 \mathrm{~A}\right)$. Indeed, while not statistically significant, cfDNA concentrations tended to increase with tumor stage (Figure 1A). No correlation was observed with tumor burden, age, or AFP concentrations.

Nonsynonymous somatic mutations were identified in 22 out of the 27 patients. While no significant differences in demographic or clinical parameters were observed between the 5 patients without detectable mutations and those 22 patients with detected mutations, patients without detectable mutations had lower AFP values (median: 20.4 vs. $99.6 \mathrm{ng} / \mathrm{mL}$ ) and were more likely to have histologically differentiated HCCs (Supplementary Table S2. Importantly, no difference in cfDNA concentrations was observed between the two patient groups (Supplementary Table S2). Furthermore, no significant differences in number of mutations detected were observed between tumor stages (Figure 1B). Among the 22 patients with detectable mutations, the number of mutations ranged from 1 to 19 , with a median number of 3. The list of all mutations is summarized in Supplementary Table S3. Androgen receptor (AR) p.P12L was the only single mutation found more than once, and both HCCs were at early stage. All detected mutated genes are shown in Figure 1C. Among them, 8 genes were mutated in more than 1 patient. The most commonly mutated gene, detected in $27 \%$ of the patients, was TP53, followed by nuclear factor erythroid 2-like 2 (NFE2L2) and beta-catenin 1 (CTNNB1), both detected in $14 \%$ of the patients, and then by lysine methyltransferases 2D (KMT2D) and 2C (KMT2C), axin 1 (AXIN1), AR, and BIVM-ERCC5, all detected in $9 \%$ of the patients. 


\section{C}

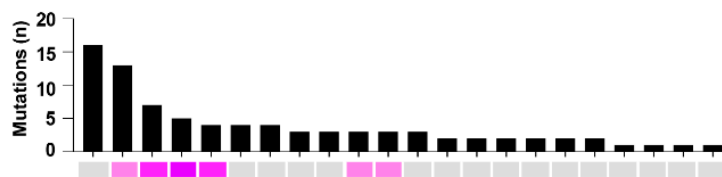

A
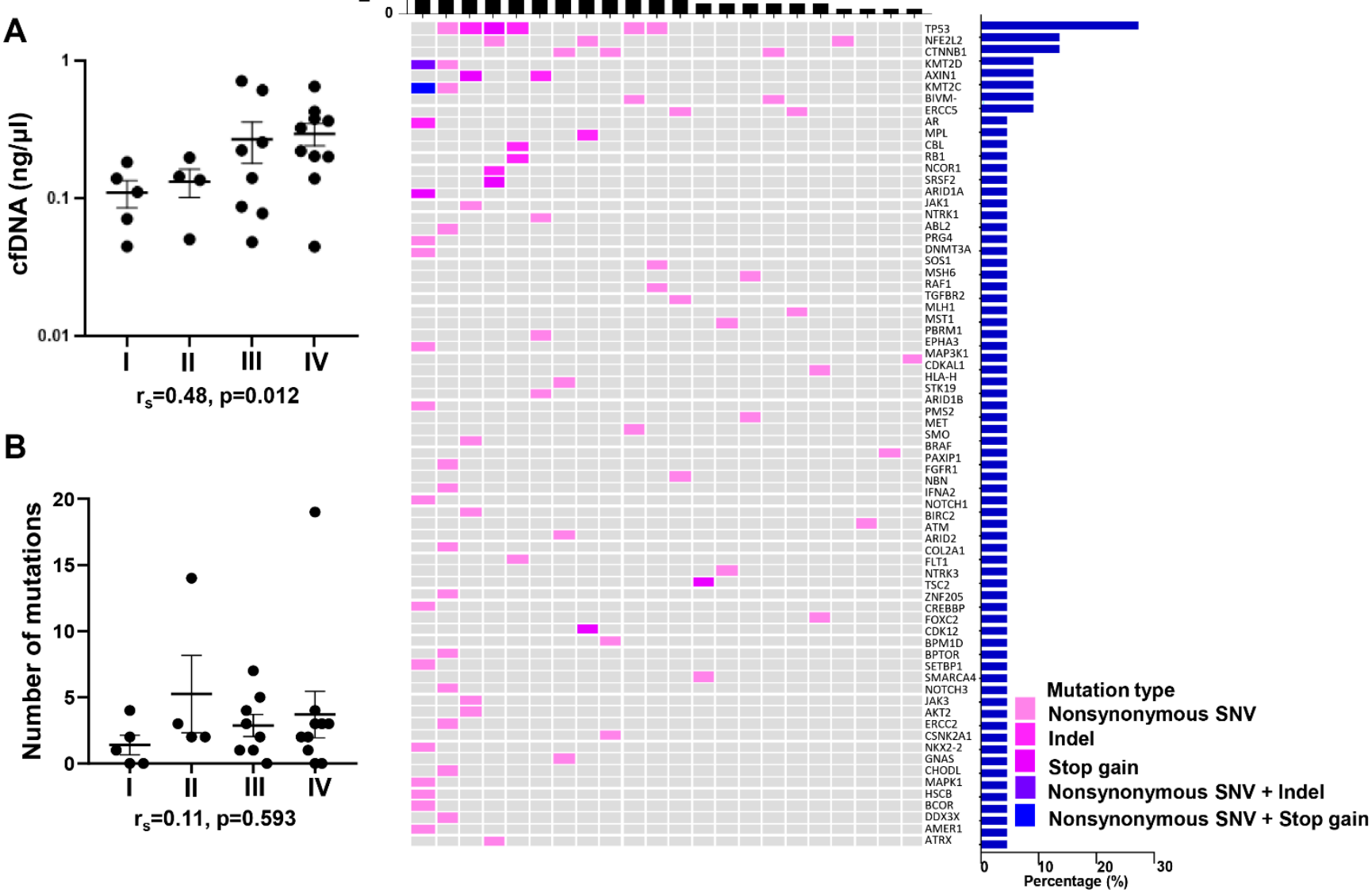

B

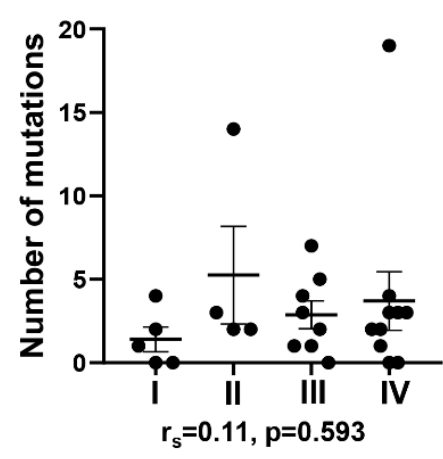

Figure 1. Mutations identified in cfDNA from Hispanic patients with HCC. (A) cfDNA concentration in Hispanic HCC patients with different tumor stages. (B) Number of mutations detected in cfDNA from Hispanic HCC patients at different tumor stages. (C) Genomic landscape of cfDNA from Hispanic subjects with HCC. The heatmap illustrates the nonsynonymous mutations detected in plasma cfDNA. The upper bars represent the number of mutations in each patient. The right bars show the frequencies of the altered genes in HCC subjects with detectable mutations. Data are presented as mean \pm SEM. $\mathrm{r}_{\mathrm{s}}$ : spearman correlation coefficient. I: HCC stage $1(n=5)$; II: HCC stage $2(n=4)$; III: HCC stage $3(n=8)$; IV: HCC stage $4(n=10)$.

\section{2. cfDNA Concentrations and Numbers and Clinical Outcome of Hispanic Patients with HCC}

We further evaluated whether concentrations or number of mutations in cfDNA of these patients with HCC could have utility in predicting prognosis. To that end, we calculated and plotted Kaplan-Meier survival curves. Patients with higher concentrations of cfDNA (Figure 2A) or with higher numbers of detected mutations (Figure 2B) had a shorter overall survival (log-rank $p<0.001$ and $p=0.045$, respectively). In multivariate analysis adjusting for tumor stage, the association remained significant $(\log$-rank $p=0.010$ and 0.057 , respectively). 
A

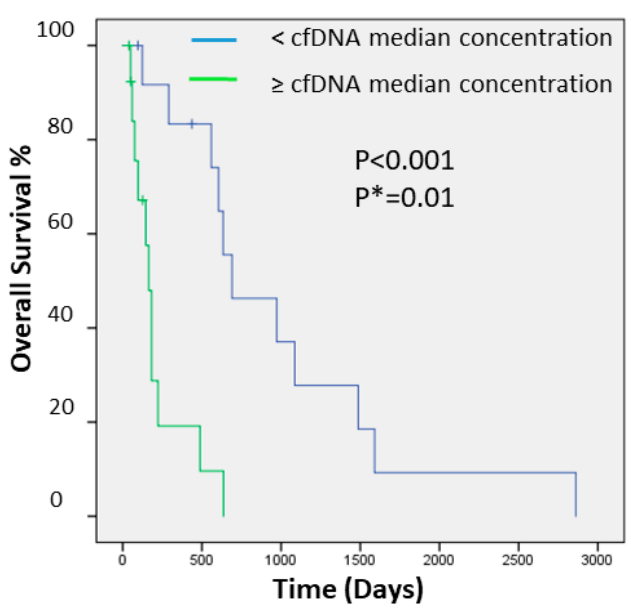

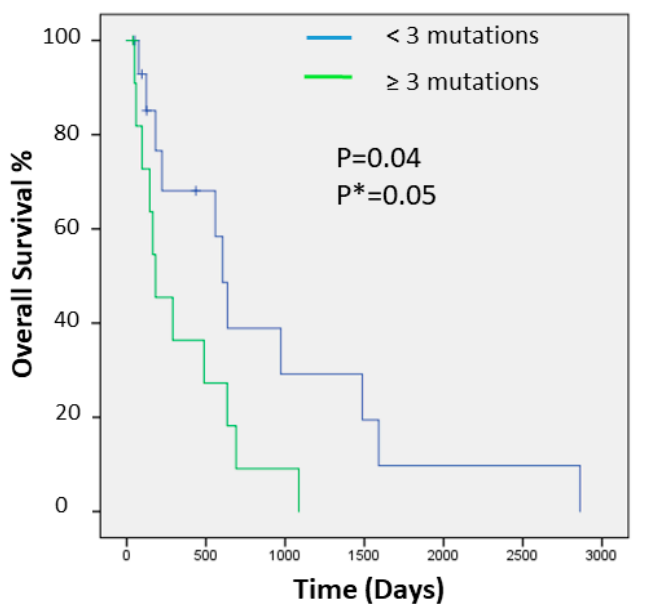

Figure 2. Kaplan-Meier curve of overall survival for HCC patients stratified by cfDNA concentration (A) and by number of mutations (B). Displayed are the Kaplan-Meier survival curves, and the $p$-values from the log-rank test. $p^{*}$ : $p$-value adjusted by tumor stage.

\subsection{Somatic Mutations in cfDNA from Hispanic Subjects with Advanced Liver Fibrosis or Cirrhosis}

We also performed targeted sequencing using the same custom T200.1 platform, on cfDNA from plasma and genomic DNA from buffy coat, collected from 51 Hispanic subjects with advanced liver fibrosis or cirrhosis, as determined by aspartate transaminase (AST) to platelet ratio index (APRI) $\geq 1$, a non-invasive scoring system for the diagnosis of cirrhosis or advanced liver fibrosis [34,35]. cfDNA and genomic DNA from Hispanic subjects from the same cohort and with APRI $<1$ were also extracted and used as controls. The clinical and demographic parameters of these study participants are summarized in Supplementary Table S4. Importantly, there was no significant difference in age and gender between the two groups. Subjects with high APRI were more likely to have abnormal liver function, with higher AST (median: 72.1 vs. $29.5 \mathrm{U} / \mathrm{L}, p<0.001$ ), higher alanine aminotransferase (ALT) (72.4 vs. $38.3 \mathrm{U} / \mathrm{L}, p<0.001)$, and lower albumin $(3.8 \mathrm{vs.} 4.1 \mathrm{~g} / \mathrm{dL}$, $p<0.001)$. HbA1c was also higher in subjects with APRI $\geq 1$ than in those with APRI $<1$ (median: $6.4 \%$ vs. $5.2 \%, p=0.018$ ), and $49 \%$ of those with APRI $\geq 1$ were diabetic compared to $28.9 \%$ of subjects with APRI $<1$. Concentrations of cfDNA were significantly higher in subjects with advanced liver fibrosis/cirrhosis compared to control subjects (median: 0.050 vs. $0.024 \mathrm{ng} / \mathrm{uL}, p<0.001$ ) (Figure 3A). Furthermore, cfDNA concentrations positively correlated with the non-invasive markers for liver fibrosis, APRI, and NAFLD fibrosis score (NFS) ( $r_{\mathrm{s}}=0.45$ and 0.40 , respectively; $\left.p<0.001\right)$. cfDNA concentrations also positively correlated with AST $\left(\mathrm{r}_{\mathrm{s}}=0.42, p<0.001\right)$ and ALT $\left(\mathrm{r}_{\mathrm{S}}=0.33, p=0.001\right)$, and negatively correlated with albumin $\left(\mathrm{r}_{\mathrm{S}}=-0.44, p<0.001\right)$ and platelet counts $\left(\mathrm{r}_{\mathrm{s}}=-0.27\right.$, $p<0.009$ ). Interestingly, there was also a positive correlation between cfDNA concentrations and BMI $\left(\mathrm{r}_{\mathrm{s}}=0.32, p=0.002\right)$, as well as waist circumference $\left(\mathrm{r}_{\mathrm{s}}=0.31, p=0.009\right)$ (Figure 3B). 


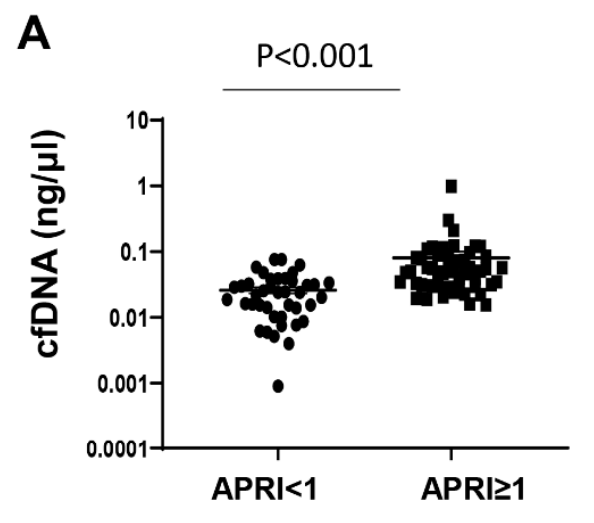

$\begin{array}{lll}\mathbf{B} & & \\ & & \\ \text { Parameters } & \mathbf{r}_{\mathbf{s}} & \mathbf{p} \\ \text { APRI } & 0.45 & <0.001 \\ \text { NFS } & 0.40 & <0.001 \\ \text { AST } & 0.42 & <0.001 \\ \text { ALT } & 0.33 & 0.001 \\ \text { Albumin } & -0.44 & <0.001 \\ \text { Platelet counts } & -0.27 & 0.009 \\ \text { BMI } & 0.32 & 0.002 \\ \text { Waist circumference } & 0.31 & 0.003\end{array}$

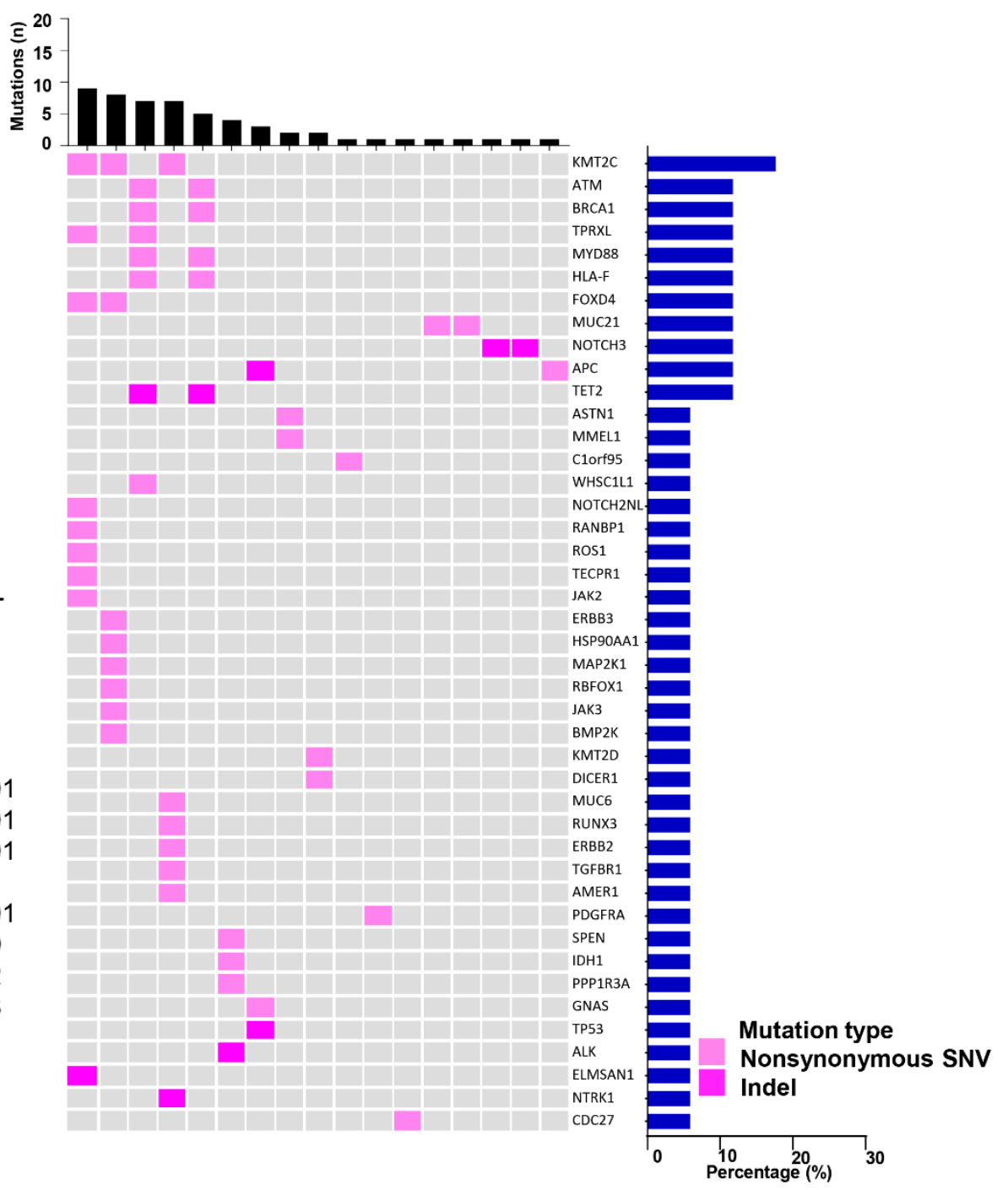

Figure 3. Mutations identified in cfDNA from Hispanic patients with advanced fibrosis/cirrhosis. (A) cfDNA concentration in plasma of subjects with APRI $<1$ and APRI $\geq 1$. (B) Clinical parameters of all CCHC subjects. (C) Genomic landscape of cfDNA from patients with advanced fibrosis/cirrhosis. Heatmap illustrating nonsynonymous mutations detected in plasma. The upper bar charts represent the number of mutations in each patient. The right bars show the frequencies of specific altered genes in the total cohort. Data are presented as mean \pm SEM. APRI, Aspartate transaminase to Platelet Ratio Index; Rs, spearman correlation coefficient; NFS, NAFLD Fibrosis Score; AST, aspartate transaminase; ALT, alanine transaminase; BMI, body mass index.

While cfDNA concentrations in control study participants were too low for targeted sequencing, all cfDNAs from subjects with advanced fibrosis/cirrhosis were sequenced successfully. Nonsynonymous mutations were identified in 17 out of the 51 subjects with advanced liver fibrosis/cirrhosis. Among those with detectable mutations, the number of mutations ranged from 1 to 9 , with a medium number of 2. Subjects with detectable mutations were more likely to be heavy drinkers $(14.3 \%$ vs. $8.8 \%, p=0.029)$ and less likely to have abnormal ALT (76.5\% vs. $94.1 \%, p=0.009)$ (Supplementary Table S5). Importantly, no significant differences in cfDNA concentrations nor APRI scores were observed between subjects with detectable mutations and subjects without detectable mutations. The mutated genes are listed in Figure 3C. Among them, 11 genes were detected mutated in more than 1 subject. The list of individual mutations is summarized in Supplementary Table S6. KMT2C was the most commonly mutated gene, occurring in $17.6 \%$ of the subjects with detectable mutations, followed by ATM serine/threonine kinase (ATM), BRCA1 
DNA repair associated (BRCA1), tetrapeptide repeat homeobox like (TPRXL), MYD88 innate immune signal transduction adaptor (MYD88), major histocompatibility complex class I F (HLA-F), forkhead box D4 (FOXD4), mucin 21, cell surface associated (MUC21), notch receptor 3 (NOTCH3), APC regulator of WNT signaling pathway (APC), and tet methylcytosine dioxygenase 2 (TET2), all occurring in $11.8 \%$ of the subjects. Mutations found in more than 1 subject included TET2 p.H860fs, TPRXL p.S219T, MYD88 p.A145T, HLA-F p.Y106C, ATM p.V2079I and p.S2146T, and BRCA1 p.R1347G.

\subsection{Concentrations and Number of Mutations in cfDNA and Clinical Outcome of Hispanic Patients with Advanced Liver Fibrosis/Cirrhosis}

Among the 51 Hispanic subjects with advanced liver fibrosis/cirrhosis, 5 subjects died: 2 from liver cancer, 1 from colon cancer, and 2 from unknown disease. Subjects who died had significantly higher concentrations of cfDNA than those subjects still currently alive ( 0.12 vs. $0.048 \mathrm{ng} / \mathrm{uL}, p=0.005$ ) (Figure $4 \mathrm{~A}$ ). They were also more likely to have detectable mutations in their cfDNA ( $80 \%$ vs. $28.3 \%, p=0.037$ ) (Figure $4 \mathrm{~A}$ ) and to have a higher number of mutations identified (median: 3 vs. 1, $p=0.014$ ) (Figure $4 \mathrm{~B}$ ). In logistic regression analysis, high levels (quartile Q4) of cfDNA concentration were strongly associated with an outcome of death (OR (95\% CI): $16.44(1.63-165.54), p=0.017)$. Similarly, presence of any mutations (OR (95\% CI): $10.15(1.04-99.60), p=0.047)$ or at least 2 mutations (OR (95\% CI): 10.00 (1.37-72.74), $p=0.023$ ) detected in cfDNA was also strongly associated with an outcome of death (Figure $4 \mathrm{C}$ ).

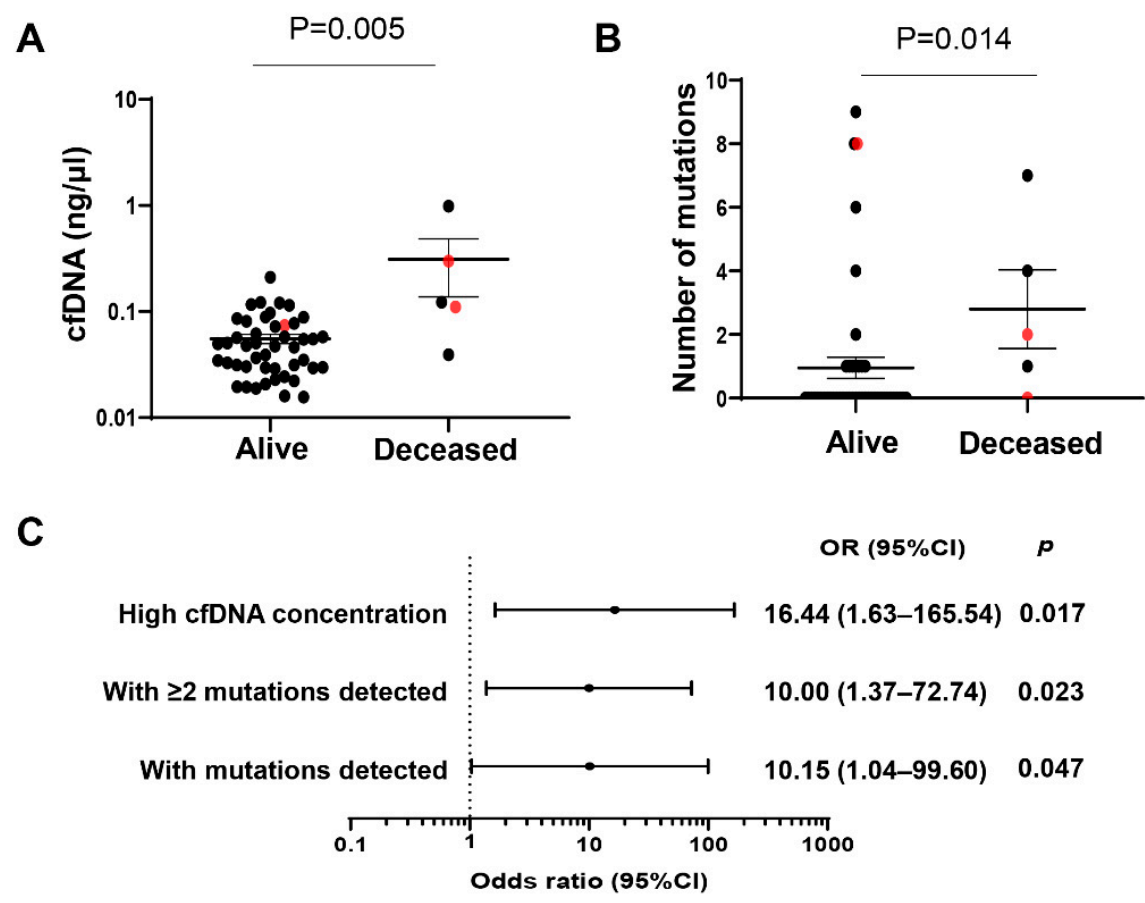

Figure 4. Mutations identified in cfDNA from Hispanic subjects with APRI $\geq 1$ correlate with an outcome of death. (A) cfDNA concentration in Hispanic subjects with APRI $\geq 1$ between alive and deceased. (B) Number of mutations detected in cfDNA in Hispanic subjects with APRI $\geq 1$ between alive and deceased. Data are presented as mean \pm SEM. Subjects with liver cancer are annotated in red. (C) Forest plot of significant associations between being deceased and high cfDNA concentration (quartile Q4) and number of mutations among subjects with APRI $\geq 1$. APRI, Aspartate transaminase to Platelet Ratio Index; OR, odds ratio; CI, confidence interval. 


\subsection{Comparison of Somatic Mutations in cfDNA between HCC Patients and Subjects with Advanced Liver Fibrosis/Cirrhosis}

Overall, mutations were more commonly identified in cfDNA from HCC patients than in cfDNA from subjects with advanced liver fibrosis/cirrhosis ( $81.5 \%$ vs. $33.3 \%, p<0.001)$, and when detected, with a higher number of mutations (median: 3 vs. $2, p<0.001$ ) (Figure 5A). In addition, cfDNA concentrations were higher in HCC patients than in subjects with advanced liver fibrosis/cirrhosis (median: 0.18 vs. $0.05 \mathrm{ng} / \mathrm{uL}, p<0.001$ ) (Figure 5B). A total of 9 genes (TP53, KMT2D, KMT2C, neurotrophic receptor tyrosine kinase 1 (NTRK1), ATM, NOTCH3, Janus Kinase 3 (JAK3), G-protein alpha stimulatory subunit (Gs $\alpha$ subunit) (GNAS), and APC membrane recruitment protein 1 (AMER1)) were found mutated in both cirrhotic/advanced fibrotic subjects and HCC patients. KMT2C p.R894Q was a common mutation identified in both groups. Ingenuity Pathway Analysis (IPA) of all genes found mutated in cfDNA of Hispanic patients with HCC identified the following as predicted upstream regulators: SP2509, an inhibitor of Lysine Demethylase 1A (KDM1A, $\left.p=4.05 \times 10^{-13}\right)$, Tazemetostat, an inhibitor of Enhancer Of Zeste 2 Polycomb Repressive Complex 2 Subunit (EZH2, $p=4.05 \times 10^{-13}$ ), and Trichostatin A, an inhibitor of Histone deacetylases (HDAC, $p=1.68 \times 10^{-13}$ ), and as top canonical pathways: hereditary breast cancer signaling $\left(p=5.05 \times 10^{-16}\right)$, embryonic stem cell pluripotency $\left(p=5.04 \times 10^{-16}\right)$, and regulation of EMT pathway $\left(p=2.69 \times 10^{-20}\right)$ (Figure 5C). IPA of all mutated genes identified in cfDNA of Hispanic subjects with advanced liver fibrosis/cirrhosis also identified embryonic stem cell pluripotency $\left(p=4.89 \times 10^{-8}\right)$ as a top canonical pathway. Other top canonical pathways included colorectal cancer metastasis signaling $\left(p=2.74 \times 10^{-8}\right)$, pancreatic adenocarcinoma signaling $\left(p=1.70 \times 10^{-9}\right)$, and IL-15 production $\left(p=1.54 \times 10^{-12}\right)$, while predicted upstream regulators included interferon gamma $\left(p=1.95 \times 10^{-6}\right)$, estrogen receptor $\left(p=4.09 \times 10^{-7}\right)$, miR-125b-5p $\left(p=2.98 \times 10^{-8}\right)$, and mir-10 $\left(p=2.14 \times 10^{-8}\right)($ Figure 5D).

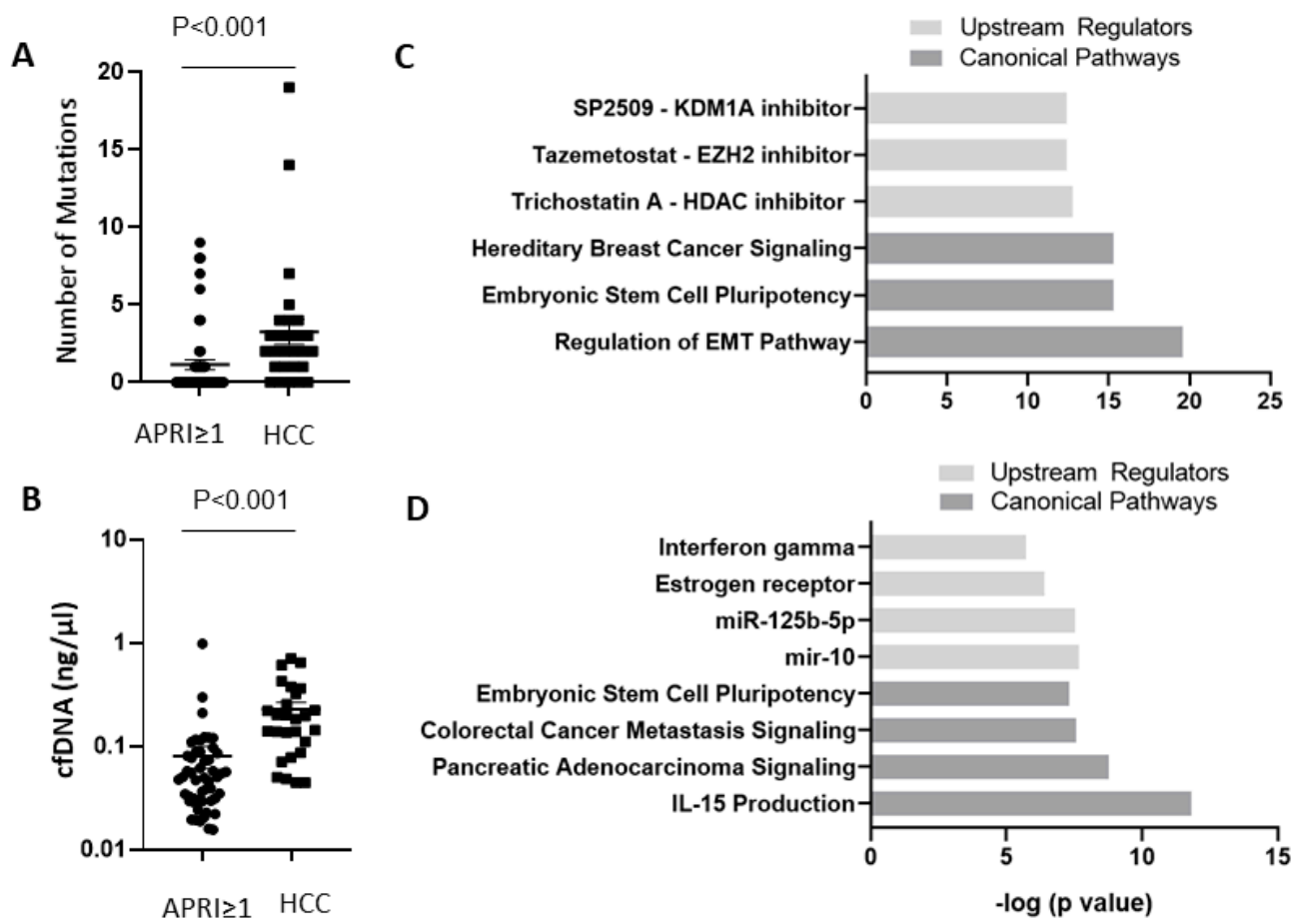

Figure 5. Hispanic patients with HCC have high numbers of mutations (A) and higher concentrations of cfDNA (B) compared to Hispanic subjects with APRI $\geq 1$. Data are presented as mean \pm SEM. (C,D) IPA core analysis identified top canonical pathways and top upstream regulators for mutated genes in cfDNA of Hispanic subjects with HCC (C) and mutated genes in cfDNA of Hispanic subjects with APRI $\geq 1$ (D). APRI, Aspartate transaminase to Platelet Ratio Index. 


\section{Discussion}

In this study, we applied targeted next-generation sequencing to the analysis of circulating cfDNA in Hispanics from South Texas with either HCC or advanced fibrosis/cirrhosis. We demonstrated the ability to detect frequently mutated genes in HCC in cfDNA of both HCC patients and cirrhotic/advanced fibrotic subjects. As the disease progressed, cfDNA concentrations and number of mutations increased. In addition, both the number of mutations and the amount of cfDNA correlated with patients' outcome. Genes found mutated in the cfDNA of Hispanic HCC patients included frequently identified HCC driver mutations, such as TP53, CTNNB1, AXIN1, RB transcriptional corepressor 1 (RB1), AT-rich interaction domain 1A (ARID1A) and 2 (ARID2), SWI/SNF related matrixassociated actin-dependent regulator of chromatin, subfamily A member 4 (SMARCA4), and NFE2L2 [32,36], with TP53 being the most commonly mutated gene. We found that mutations in CTNNB1 were more likely to be identified in patients with alcoholic cirrhosis, which is consistent with the previous reports of association of CTNNB1 mutation with alcoholism [37,38]. A repeated mutation in AR was also found in patients with early-stage $\mathrm{HCC}$ and absence of common risk factors, including $\mathrm{HCV}, \mathrm{HBV}$, or alcoholic cirrhosis. Although AR mutations are relatively rare events in HCC according to TCGA (occurs in $2.7 \%$ of patients), AR has been linked to gender disparity [39] and pathogenesis of HCC in multiple animal models [40-42]. Moreover, recently, an AR-driven oncogene, cell cycle-related kinase (CCRK), collaborated with obesity-induced pro-inflammatory signaling to promote NASH-related hepatocarcinogenesis [43]. Given the small number of patients, the identified associations of mutation in cfDNA with HCC risk factors require further validation.

Major studies of cfDNA for HCC have focused on druggable (actionable) mutations or already known, putative genes with frequent association with HCC [44-47]. It was reported that cfDNA had a slightly higher efficiency than single tumor specimens ( $84.2 \%$ vs. $78.9 \%)$ to identify 19 mutations with therapeutic potential (from NCI-MATCH trial or indicative of target drugs) [45]. cfDNA also has values in predicting treatment efficacy. Targeted sequencing in 13 unresectable HCC cases identified a high percentage $(68 \%)$ of variants found after sorafenib treatment, indicative of clonal selection [48]. In our study, candidate druggable mutations (e.g., JAK1 and NOTCH3) have also been identified. However, in a study evaluating druggable mutations in 10,000 cancer samples from 62 tumor types, HCC is ranked as second-to-last in terms of prevalence of druggable mutations [49].

cfDNA analyses hold promising early diagnostic value for HCC. An assay combining detection of mutations in TP53, CTNNB1, AXIN1, and TERT promoter, HBV integration site, and serum markers AFP and des $\gamma$ carboxy prothrombin (DCP) was developed. This assay separated HCC from non-HCC with a sensitivity of $85 \%$ and a specificity of $93 \%$ among individuals who had liver nodules and/or elevated AFP. Furthermore, it could identify early-stage HCC from asymptomatic HBsAg-positive individuals during 6-8 months follow-up [50]. However, this study focused exclusively on Chinese patients with HBV-related HCC. Whether this assay is applicable to other patient populations and etiologies is unknown. Our study provided additional candidate genes which merit further investigation for early diagnosis. Among the mutations identified in the cfDNA of subjects with advanced fibrosis/cirrhosis, somatic mutations in TP53, APC, KMT2C, KMT2D, ATM, and ERBB2 were also reported in the liver with chronic liver diseases, including cirrhosis [51-53]. Several genes may play pivotal roles in early stages of hepatocarcinogenesis. Liver-specific disruption of APC leads to activated $\beta$-catenin signaling, resulting in hepatomegaly and HCC in mice [54]. NOTCH3 regulates the differentiation of fetal liver stem/progenitor cells into hepatocytes [55] and bile duct development [56]. One subject with advanced fibrosis/cirrhosis had a mutation in the proline-glutamic acidserine-threonine (PEST) domain (p.P2034fs) of NOTCH3, which leads to activated NOTCH signaling and a subsequent oncogenic event [57]. GNAS is a gene recurrently mutated in inflammatory liver tumors, leading to activation of pSTAT3 $[58,59]$. 
Besides specific mutations in cfDNA, cfDNA concentrations and number of mutations correlated with disease progression. We also found that cfDNA concentrations and number of mutations correlated with worse outcome in HCC patients, in agreement with a previous report [60]. cfDNA levels and number of mutations increased from advanced fibrosis/cirrhosis to HCC, and cfDNA levels were positively correlated with non-invasive markers for liver fibrosis (APRI and NFS) and degree of hepatic damage (AST, ALT). In the setting of NAFLD, cfDNA levels have been found to correlate with NAFLD severity [61]. In our study, a positive correlation between cfDNA concentrations and obesity or visceral obesity was observed. The results are also consistent with previous publications reporting that cfDNA levels are significantly higher in patients with computed tomography-determined visceral obesity [62], and positively correlated with BMI in HCC patients [63].

Stemness and epithelial-mesenchymal transition (EMT) are regarded as two fundamental characteristics of liver cancer stem cells necessary for cancer progression [64]. Remarkably, embryonic stem cell pluripotency was identified by IPA as a top canonical pathways of both genes mutated in cfDNA of HCC subjects and genes mutated in cfDNA in subjects with advanced fibrosis/cirrhosis, suggesting an essential role in both HCC development and HCC progression. It was previously suggested that DNA damage repair signaling is essential for the maintenance of stem cell pluripotency in HCC [65] and that p38 MAPK signaling, leading to F-actin reorganization and activation of nuclear factor erythroid 2-related factor 2-mediated oxidative stress response, collectively contribute to enhanced stemness of HCC cells [66]. EMT was identified as a top canonical pathway only in IPA analysis of HCC mutated genes, confirming its essential role in HCC progression in this study population as well. Interestingly, it was suggested that circulating tumor cells undergoing EMT provide a metric for diagnosis and prognosis of patients with HCC [67]. IPA analysis also suggested a major role of hypoxia, immune surveillance, and natural killer cells through interferon-gamma or IL-15 production, in early events, and highlighted the role of epigenetics in HCC progression. KDM1A forms repressive complexes with HDAC1, regulating differentiation of liver progenitor cells $[68,69]$. Epigenetic modulation enhances immunotherapy for HCC [70]. EZH2 regulates PD-L1 expression [71] and natural killer cells [72] in HCC.

This study is highly innovative. It is the first description of HCC somatic mutations detected in cfDNA in Hispanics, the population in the United States with the highest incidence of HCC. It is also the first comparative study of somatic mutations detected in cfDNA from subjects with HCC and subjects with advanced liver fibrosis/cirrhosis, including biological pathways associated with the identified mutations. Finally, it is the first report of the potential utility of cfDNA features such as concentration and mutations number in predicting overall survival in non-cancer subjects.

HCC is a highly heterogenous disease [73,74], with a diversity of low-incidence, nonsynonymous point mutations. In addition to mutations in driver genes, mutations in passenger genes also have the potential to dynamically correlate with tumor burden [75]. The custom panel we used was not specifically designed for HCC known mutated genes. A panel including only driver genes may fail to provide sufficient coverage. However, including more genes in an assay could also greatly increase the cost, a major challenge for cfDNA clinical application for early detection.

In conclusion, we identified somatic mutations in circulating cfDNA of patients with HCC and in subjects with cirrhosis/advanced fibrosis and therefore at risk for HCC. Together with other cfDNA features such as concentration and mutations number, these mutations could have utility in identifying high-risk subjects for surveillance of HCC.

\section{Materials and Methods}

\subsection{Study Participants and Sample Collection}

The study was approved by the Committee for the Protection of Human Subjects of the University of Texas Health Science Center at Houston and the MD Anderson Cancer Center. Peripheral blood from all study participants was drawn into EDTA tubes. Plasma 
and separated blood cells were aliquoted and stored at $-80^{\circ} \mathrm{C}$ until analysis. Biospecimens from 27 Hispanic patients with HCC were obtained from a MD Anderson Cancer Center sample biorepository for patients with histologically confirmed HCC. Demographic and clinical parameters of these patients are shown in Supplementary Table S1. Family history of cancer refers to family history of cancer in first-degree relatives. Fifty-one Hispanics with advanced liver fibrosis or cirrhosis and 41 Hispanics without advanced fibrosis or cirrhosis were selected from the Cameron County Hispanic Cohort (CCHC) [76]. Presence of advanced liver fibrosis/cirrhosis was based on APRI scores $\geq 1$. APRI scores were calculated as $(\mathrm{AST} / 33 \mathrm{IU} / \mathrm{L}) /$ platelet count $\times 100$ [77]. Demographic and clinical parameters of these 92 study participants are shown in Supplementary Table S4. Diabetes was defined using the 2010 American Diabetes Association (ADA) definition [78]. Excess alcohol consumption was defined as $>2$ drinks / day for men and $>1$ drink/day for women within 1 year before the completion of data collection. The reported laboratory tests were measured at CLIA-approved reference laboratories. NAFLD fibrosis score (NFS) was calculated as:

$$
\begin{gathered}
\text { NFS }=-1.675+0.037 \times \text { age }(\text { year })+0.094 \times \text { BMI }\left(\mathrm{kg} / \mathrm{m}^{2}\right)+1.13 \times \text { fasting blood } \\
\text { glucose } \geq 100 / \text { diabetes }(\text { yes }=1, \text { no }=0)+0.99 \times \text { AST } / \text { ALT ratio }-0.013 \times \\
\text { platelet count }\left(\times 10^{9} / \mathrm{L}\right)-0.66 \times \text { albumin }(\mathrm{g} / \mathrm{dL})
\end{gathered}
$$

\subsection{DNA Extraction, Quality Control, and Quantification}

Genomic DNA was extracted from $200 \mu \mathrm{L}$ of buffy coat using the QIAamp DNA blood mini kit (Qiagen Co. Ltd., DE, Düsseldorf, Germany). Circulating cfDNA was extracted from $500 \mu \mathrm{L}$ of plasma using the QIAamp circulating nucleic acid kit (Qiagen Co. Ltd., DE). DNA quality was assessed using a fragment analyzer and high-sensitivity genomic DNA analysis kit (Advanced Analytical Technologies). cfDNA quantification was performed according to the smear analysis function of the PROSize 2.0 configuration menu (Advanced Analytical Technologies), specifying a size range of 75-225 bp [79].

\subsection{Targeted Sequencing and Bioinformatics Analysis}

Targeted sequencing was performed by the Sequencing and Microarray Facility at MD Anderson Cancer Center. Briefly, indexed libraries were prepared from $500 \mathrm{ng}$ of Diagenode Biorupter sheared genomic DNA (buffy coat) and up to $45 \mathrm{ng}$ of cfDNA (plasma) using the KAPA Hyper Library Preparation Kit (Kapa Biosystems, Inc., Wilmington, MA, USA). Library quality was assessed using the Fragment Analyzer High-Sensitivity NGS Fragment Analysis Kit (Advanced Analytical Technologies). The libraries were then prepared for capture with 8 cycles of pre-LM-PCR amplification. Following pre-LM-PCR, amplified libraries were assessed for quality using the Fragment Analyzer High-Sensitivity NGS Fragment Analysis Kit and quantity using the Qubit dsDNA HS Assay Kit (ThermoFisher, Waltham, MA, USA), then pooled in batches of 3-6 amplified libraries/pool. Targeted capture was performed using a Nimblegen custom targeted solid tumor panel (T200.1) developed at MD Anderson Cancer Center. T200.1 is designed to identify actionable and clinically relevant DNA alteration to cfDNA samples for noninvasive detection of rare mutations in circulating cfDNA. The T200.1 panel covers 262 cancer-associated genes [80]. The enriched libraries were PCR-amplified for 9 cycles post-capture, then assessed for: quality using the Fragment Analyzer, enrichment efficiency by qPCR, and quantified using the Qubit dsDNA HS Assay Kit (ThermoFisher). Sequencing was performed on the HiSeq4000 Sequencer (Illumina Inc., San Diego, CA, USA), 3 samples per lane (6 in 2 lanes), using the $76 \mathrm{nt}$ paired end configuration. The mean coverage of our sample was $322 \mathrm{X}$.

BCL (raw output of Illumina HigSeq) files were processed using Illumina's Consensus Assessment of Sequence and Variation (CASAVA) tool (Illumina. Available online: http: / / support.illumina.com/sequencing/sequencing_software/casava.html (accessed on 1 July 2016)) for demultiplexing/conversion to FASTQ format, which is the standard input for most aligners and downstream analytic tools. For DNA samples, the FASTQ files were aligned to the reference genome (human Hg19) using BWA [81] with 3 mismatches, with 
2 in the first 40 seed regions for a 76 bases sequencing run. The aligned BAM files were subjected to mark duplication, re-alignment, and re-calibration using Picard and GATK [82] before any downstream analyses. Somatic mutations were found using MuTect [83] and indels using Mutation, and indel results were subjected to filtering by excluding events with less than 20 and 10 bases covering the event for the tumor and normal samples, respectively. For mutations, events with altered base allele frequency less than $2 \%$ for cfDNA and greater than $2 \%$ in genomic DNA were also excluded. For indels, a 5\% tumor allele frequency was used to account for the high false positive rates. Somatic variants were confirmed through visual inspections using IGV (Integrative Genomics Viewer. Available online: http:/ / software.broadinstitute.org/software/igv/ (accessed on 1 September 2016)).

\subsection{Statistical Analysis}

Fisher's exact tests were used to test the association of mutations with patient characteristics. Overall survival was examined to compare the prognosis of the patients with more than or equal to 3 mutations to those less than 3 mutations. Using SPSS (version 24), the results were displayed as Kaplan-Meier plots with $p$-values from a log-rank test and Cox proportional hazards regression. Logistic regression was performed using SPSS to estimate the odds ratio (OR) and 95\% confidence interval (CI) for association of mutations in cfDNA with the worse outcome (death).

\subsection{Ingenuity Pathway Analysis}

QIAGEN's Ingenuity ${ }^{\circledR}$ Pathway Analysis (Ingenuity ${ }^{\circledR}$ Pathway Analysis, IPA ${ }^{\circledR}$. Available online: www.qiagen.com/ingenuity (accessed on 17 July 2019)) core analysis was performed using either all genes found mutated in cfDNA of Hispanic patients with HCC or all mutated genes found in cfDNA of Hispanic subjects with cirrhosis/advanced fibrosis. Top upstream regulators and top canonical pathways were graphed using $-\log (p$-values) in Graphpad Prism 9.

Supplementary Materials: The following are available online at https: / www.mdpi.com/article/ 10.3390/ijms22147411/s1, Table S1: Demographic and clinical parameters of the 27 Hispanic participants with HCC, Table S2: Comparison between Hispanic HCC participants with detected mutations and those without detectable mutations in cfDNA, Table S3: List of somatic mutations detected by targeted sequencing in cfDNA from Hispanic patients with HCC, Table S4: Demographic and clinical parameters of the 51 Hispanic study participants with APRI $\geq 1$ and 41 Hispanic study participants with APRI $\leq 1$, Table S5: Comparison between the Hispanic subjects with advanced liver fibrosis/cirrhosis with detected mutations and those without detectable mutations, Table S6: List of somatic mutations detected by targeted sequencing in cfDNA in Hispanic study participants with APRI $\geq 1$.

Author Contributions: Conceptualization, J.J. and L.B.; Methodology, J.J., E.J.T., P.A.F. and J.Z.; Formal analysis, J.J., J.I.S., X.M. and J.Z.; Resources, J.B.M. and S.P.F.-H.; Writing-original draft preparation, J.J.; Writing-review and editing, J.J., J.I.S. and L.B.; Supervision, L.B.; funding acquisition, L.B. All authors have read and agreed to the published version of the manuscript.

Funding: This work was supported by the NCI R01CA204665 grant to L.B. and by NCI CA016672 to the Sequencing and Microarray Facility at MD Anderson Cancer Center.

Institutional Review Board Statement: The study was conducted according to the guidelines of the Declaration of Helsinki, and approved by the Institutional Review Board of The University of Texas MD Anderson Cancer Center.

Informed Consent Statement: Informed consent was obtained from all subjects involved in the study.

Data Availability Statement: The data presented in this study are available upon request from the corresponding author.

Acknowledgments: We thank Rocío Uribe who recruited and interviewed the Hispanic participants in South Texas, Marcela Morris, BS and Hugo Soriano for laboratory and data support, and Valley Baptist Medical Center, Brownsville, Texas, for providing space for a Clinical Research Unit. 
Conflicts of Interest: The authors declare no conflict of interest.

\section{References}

1. Siegel, R.L.; Miller, K.D.; Jemal, A. Cancer statistics, 2019. CA A Cancer J. Clin. 2019, 69, 7-34. [CrossRef] [PubMed]

2. Committee, A.C.P.R.W.; Sawyers, C.L.; Abate-Shen, C.; Anderson, K.C.; Barker, A.; Baselga, J.; Berger, N.A.; Foti, M.; Jemal, A.; Lawrence, T.S.; et al. AACR Cancer Progress Report 2013. Clin. Cancer Res. 2013, 19, S4-S98. [CrossRef]

3. El-Serag, H.B. Hepatocellular carcinoma. N. Engl. J. Med. 2011, 365, 1118-1127. [CrossRef] [PubMed]

4. Roayaie, S.; Jibara, G.; Tabrizian, P.; Park, J.W.; Yang, J.; Yan, L.; Schwartz, M.; Han, G.; Izzo, F.; Chen, M.; et al. The role of hepatic resection in the treatment of hepatocellular cancer. Hepatology 2015, 62, 440-451. [CrossRef]

5. Roayaie, S.; Obeidat, K.; Sposito, C.; Mariani, L.; Bhoori, S.; Pellegrinelli, A.; Labow, D.; Llovet, J.M.; Schwartz, M.; Mazzaferro, V. Resection of hepatocellular cancer $\leq 2 \mathrm{~cm}$ : Results from two Western centers. Hepatology 2013, 57, 1426-1435. [CrossRef] [PubMed]

6. Kulik, L.; El-Serag, H.B. Epidemiology and Management of Hepatocellular Carcinoma. Gastroenterology 2019, 156, 477-491. [CrossRef]

7. Di Tommaso, L.; Sangiovanni, A.; Borzio, M.; Park, Y.N.; Farinati, F.; Roncalli, M. Advanced precancerous lesions in the liver. Best Pract. Res. Clin. Gastroenterol. 2013, 27, 269-284. [CrossRef]

8. Ricke, J.; Bulla, K.; Kolligs, F.; Peck-Radosavljevic, M.; Reimer, P.; Sangro, B.; Schott, E.; Schutte, K.; Verslype, C.; Walecki, J.; et al. Safety and toxicity of radioembolization plus Sorafenib in advanced hepatocellular carcinoma: Analysis of the European multicentre trial SORAMIC. Liver Int. 2015, 35, 620-626. [CrossRef] [PubMed]

9. White, D.L.; Thrift, A.P.; Kanwal, F.; Davila, J.; El-Serag, H.B. Incidence of Hepatocellular Carcinoma in All 50 United States, From 2000 Through 2012. Gastroenterology 2017, 152, 812-820. [CrossRef]

10. Jiao, J.; Watt, G.P.; Lee, M.; Rahbar, M.H.; Vatcheva, K.P.; Pan, J.J.; McCormick, J.B.; Fisher-Hoch, S.P.; Fallon, M.B.; Beretta, L. Cirrhosis and Advanced Fibrosis in Hispanics in Texas: The Dominant Contribution of Central Obesity. PLoS ONE 2016, 11, e0150978. [CrossRef]

11. Watt, G.P.; Lee, M.; Pan, J.J.; Fallon, M.B.; Loomba, R.; Beretta, L.; McCormick, J.B.; Fisher-Hoch, S.P. High Prevalence of Hepatic Fibrosis, Measured by Elastography, in a Population-Based Study of Mexican Americans. Clin. Gastroenterol. Hepatol. 2019, 17, 968-975. [CrossRef] [PubMed]

12. Schwarzenbach, H.; Hoon, D.S.; Pantel, K. Cell-free nucleic acids as biomarkers in cancer patients. Nat. Rev. Cancer 2011, 11, 426-437. [CrossRef] [PubMed]

13. Kumar, P.; Dillon, L.W.; Shibata, Y.; Jazaeri, A.A.; Jones, D.R.; Dutta, A. Normal and Cancerous Tissues Release Extrachromosomal Circular DNA (eccDNA) into the Circulation. Mol. Cancer Res. 2017, 15, 1197-1205. [CrossRef]

14. Heitzer, E.; Haque, I.S.; Roberts, C.E.S.; Speicher, M.R. Current and future perspectives of liquid biopsies in genomics-driven oncology. Nat. Rev. Genet. 2019, 20, 71-88. [CrossRef] [PubMed]

15. Oshiro, C.; Kagara, N.; Naoi, Y.; Shimoda, M.; Shimomura, A.; Maruyama, N.; Shimazu, K.; Kim, S.J.; Noguchi, S. PIK3CA mutations in serum DNA are predictive of recurrence in primary breast cancer patients. Breast Cancer Res. Treat. 2015, 150, 299-307. [CrossRef] [PubMed]

16. Vazquez, S.; Casal, J.; Afonso Afonso, F.J.; Firvida, J.L.; Santome, L.; Baron, F.; Lazaro, M.; Pena, C.; Amenedo, M.; Abdulkader, I.; et al. EGFR testing and clinical management of advanced NSCLC: A Galician Lung Cancer Group study (GGCP 048-10). Cancer Manag. Res. 2016, 8, 11-20. [CrossRef]

17. Murtaza, M.; Dawson, S.J.; Tsui, D.W.; Gale, D.; Forshew, T.; Piskorz, A.M.; Parkinson, C.; Chin, S.F.; Kingsbury, Z.; Wong, A.S.; et al. Non-invasive analysis of acquired resistance to cancer therapy by sequencing of plasma DNA. Nature 2013, 497, 108-112. [CrossRef]

18. Bettegowda, C.; Sausen, M.; Leary, R.J.; Kinde, I.; Wang, Y.; Agrawal, N.; Bartlett, B.R.; Wang, H.; Luber, B.; Alani, R.M.; et al. Detection of circulating tumor DNA in early- and late-stage human malignancies. Sci. Transl. Med. 2014, 6, 224ra224. [CrossRef]

19. Goldberg, S.B.; Narayan, A.; Kole, A.J.; Decker, R.H.; Teysir, J.; Carriero, N.J.; Lee, A.; Nemati, R.; Nath, S.K.; Mane, S.M.; et al. Early Assessment of Lung Cancer Immunotherapy Response via Circulating Tumor DNA. Clin. Cancer Res. 2018, 24, 1872-1880. [CrossRef]

20. Cohen, J.D.; Javed, A.A.; Thoburn, C.; Wong, F.; Tie, J.; Gibbs, P.; Schmidt, C.M.; Yip-Schneider, M.T.; Allen, P.J.; Schattner, M.; et al. Combined circulating tumor DNA and protein biomarker-based liquid biopsy for the earlier detection of pancreatic cancers. Proc. Natl. Acad. Sci. USA 2017, 114, 10202-10207. [CrossRef]

21. Phallen, J.; Sausen, M.; Adleff, V.; Leal, A.; Hruban, C.; White, J.; Anagnostou, V.; Fiksel, J.; Cristiano, S.; Papp, E.; et al. Direct detection of early-stage cancers using circulating tumor DNA. Sci. Transl. Med. 2017, 9. [CrossRef]

22. Cohen, J.D.; Li, L.; Wang, Y.; Thoburn, C.; Afsari, B.; Danilova, L.; Douville, C.; Javed, A.A.; Wong, F.; Mattox, A.; et al. Detection and localization of surgically resectable cancers with a multi-analyte blood test. Science 2018, 359, 926-930. [CrossRef]

23. Fiala, C.; Diamandis, E.P. Utility of circulating tumor DNA in cancer diagnostics with emphasis on early detection. BMC Med. 2018, 16, 166. [CrossRef] [PubMed]

24. Alborelli, I.; Generali, D.; Jermann, P.; Cappelletti, M.R.; Ferrero, G.; Scaggiante, B.; Bortul, M.; Zanconati, F.; Nicolet, S.; Haegele, J.; et al. Cell-free DNA analysis in healthy individuals by next-generation sequencing: A proof of concept and technical validation study. Cell Death Dis. 2019, 10, 534. [CrossRef] 
25. Kirk, G.D.; Camus-Randon, A.M.; Mendy, M.; Goedert, J.J.; Merle, P.; Trepo, C.; Brechot, C.; Hainaut, P.; Montesano, R. Ser-249 p53 mutations in plasma DNA of patients with hepatocellular carcinoma from The Gambia. J. Natl. Cancer Inst. 2000, 92, 148-153. [CrossRef]

26. Huang, X.H.; Sun, L.H.; Lu, D.D.; Sun, Y.; Ma, L.J.; Zhang, X.R.; Huang, J.; Yu, L. Codon 249 mutation in exon 7 of p53 gene in plasma DNA: Maybe a new early diagnostic marker of hepatocellular carcinoma in Qidong risk area, China. World J. Gastroenterol. WJG 2003, 9, 692-695. [CrossRef]

27. Hosny, G.; Farahat, N.; Tayel, H.; Hainaut, P. Ser-249 TP53 and CTNNB1 mutations in circulating free DNA of Egyptian patients with hepatocellular carcinoma versus chronic liver diseases. Cancer Lett. 2008, 264, 201-208. [CrossRef] [PubMed]

28. Ortiz-Cuaran, S.; Villar, S.; Gouas, D.; Ferro, G.; Plymoth, A.; Khuhaprema, T.; Kalalak, A.; Sangrajrang, S.; Friesen, M.D.; Groopman, J.D.; et al. Association between HBX status, aflatoxin-induced R249S TP53 mutation and risk of hepatocellular carcinoma in a case-control study from Thailand. Cancer Lett. 2013, 331, 46-51. [CrossRef] [PubMed]

29. Jiao, J.; Niu, W.; Wang, Y.; Baggerly, K.; Ye, Y.; Wu, X.; Davenport, D.; Almeda, J.L.; Betancourt-Garcia, M.M.; Forse, R.A.; et al. Prevalence of Aflatoxin-Associated TP53R249S Mutation in Hepatocellular Carcinoma in Hispanics in South Texas. Cancer Prev. Res. 2018, 11, 103-112. [CrossRef] [PubMed]

30. Nault, J.C.; Mallet, M.; Pilati, C.; Calderaro, J.; Bioulac-Sage, P.; Laurent, C.; Laurent, A.; Cherqui, D.; Balabaud, C.; Zucman-Rossi, J. High frequency of telomerase reverse-transcriptase promoter somatic mutations in hepatocellular carcinoma and preneoplastic lesions. Nat. Commun. 2013, 4, 2218. [CrossRef] [PubMed]

31. Nault, J.C.; Zucman-Rossi, J. TERT promoter mutations in primary liver tumors. Clin. Res. Hepatol. Gastroenterol. 2016, 40, 9-14. [CrossRef] [PubMed]

32. Cancer Genome Atlas Research Network. Comprehensive and Integrative Genomic Characterization of Hepatocellular Carcinoma. Cell 2017, 169, 1327-1341. [CrossRef] [PubMed]

33. Jiao, J.; Watt, G.P.; Stevenson, H.L.; Calderone, T.L.; Fisher-Hoch, S.P.; Ye, Y.; Wu, X.; Vierling, J.M.; Beretta, L. Telomerase reverse transcriptase mutations in plasma DNA in patients with hepatocellular carcinoma or cirrhosis: Prevalence and risk factors. Hepatol. Commun. 2018, 2, 718-731. [CrossRef] [PubMed]

34. Lin, Z.H.; Xin, Y.N.; Dong, Q.J.; Wang, Q.; Jiang, X.J.; Zhan, S.H.; Sun, Y.; Xuan, S.Y. Performance of the aspartate aminotransferaseto-platelet ratio index for the staging of hepatitis C-related fibrosis: An updated meta-analysis. Hepatology 2011, 53, 726-736. [CrossRef]

35. Xiao, G.; Yang, J.; Yan, L. Comparison of diagnostic accuracy of aspartate aminotransferase to platelet ratio index and fibrosis-4 index for detecting liver fibrosis in adult patients with chronic hepatitis B virus infection: A systemic review and meta-analysis Hepatology 2015, 61, 292-302. [CrossRef]

36. Chaudhary, K.; Poirion, O.B.; Lu, L.; Huang, S.; Ching, T.; Garmire, L.X. Multimodal Meta-Analysis of 1,494 Hepatocellular Carcinoma Samples Reveals Significant Impact of Consensus Driver Genes on Phenotypes. Clin. Cancer Res. Off. J. Am. Assoc. Cancer Res. 2019, 25, 463-472. [CrossRef]

37. Rebouissou, S.; Franconi, A.; Calderaro, J.; Letouze, E.; Imbeaud, S.; Pilati, C.; Nault, J.C.; Couchy, G.; Laurent, A.; Balabaud, C.; et al. Genotype-phenotype correlation of CTNNB1 mutations reveals different ss-catenin activity associated with liver tumor progression. Hepatology 2016, 64, 2047-2061. [CrossRef]

38. Khemlina, G.; Ikeda, S.; Kurzrock, R. The biology of Hepatocellular carcinoma: Implications for genomic and immune therapies. Mol. Cancer 2017, 16, 149. [CrossRef]

39. Ma, W.L.; Lai, H.C.; Yeh, S.; Cai, X.; Chang, C. Androgen receptor roles in hepatocellular carcinoma, fatty liver, cirrhosis and hepatitis. Endocr. Relat. Cancer 2014, 21, R165-R182. [CrossRef]

40. Ma, W.L.; Hsu, C.L.; Wu, M.H.; Wu, C.T.; Wu, C.C.; Lai, J.J.; Jou, Y.S.; Chen, C.W.; Yeh, S.; Chang, C. Androgen receptor is a new potential therapeutic target for the treatment of hepatocellular carcinoma. Gastroenterology 2008, 135, 947-955. [CrossRef] [PubMed]

41. Wu, M.H.; Ma, W.L.; Hsu, C.L.; Chen, Y.L.; Ou, J.H.; Ryan, C.K.; Hung, Y.C.; Yeh, S.; Chang, C. Androgen receptor promotes hepatitis B virus-induced hepatocarcinogenesis through modulation of hepatitis B virus RNA transcription. Sci. Transl. Med. 2010, 2, 32ra35. [CrossRef]

42. Li, H.; Li, Y.; Lu, J.W.; Huo, X.; Gong, Z. Liver-specific androgen receptor knockout attenuates early liver tumor development in zebrafish. Sci. Rep. 2019, 9, 10645. [CrossRef]

43. Sun, H.; Yang, W.; Tian, Y.; Zeng, X.; Zhou, J.; Mok, M.T.S.; Tang, W.; Feng, Y.; Xu, L.; Chan, A.W.H.; et al. An inflammatory-CCRK circuitry drives mTORC1-dependent metabolic and immunosuppressive reprogramming in obesity-associated hepatocellular carcinoma. Nat. Commun. 2018, 9, 5214. [CrossRef]

44. Howell, J.; Atkinson, S.R.; Pinato, D.J.; Knapp, S.; Ward, C.; Minisini, R.; Burlone, M.E.; Leutner, M.; Pirisi, M.; Buttner, R.; et al. Identification of mutations in circulating cell-free tumour DNA as a biomarker in hepatocellular carcinoma. Eur. J. Cancer 2019, 116, 56-66. [CrossRef] [PubMed]

45. Huang, A.; Zhao, X.; Yang, X.R.; Li, F.Q.; Zhou, X.L.; Wu, K.; Zhang, X.; Sun, Q.M.; Cao, Y.; Zhu, H.M.; et al. Circumventing intratumoral heterogeneity to identify potential therapeutic targets in hepatocellular carcinoma. J. Hepatol. 2017, 67, 293-301. [CrossRef] 
46. Labgaa, I.; Villacorta-Martin, C.; D’Avola, D.; Craig, A.J.; von Felden, J.; Martins-Filho, S.N.; Sia, D.; Stueck, A.; Ward, S.C.; Fiel, M.I.; et al. A pilot study of ultra-deep targeted sequencing of plasma DNA identifies driver mutations in hepatocellular carcinoma. Oncogene 2018, 37, 3740-3752. [CrossRef] [PubMed]

47. Kaseb, A.O.; Sanchez, N.S.; Sen, S.; Kelley, R.K.; Tan, B.; Bocobo, A.G.; Lim, K.H.; Abdel-Wahab, R.; Uemura, M.; Pestana, R.C.; et al. Molecular Profiling of Hepatocellular Carcinoma Using Circulating Cell-Free DNA. Clin. Cancer Res. Off. J. Am. Assoc. Cancer Res. 2019, 25, 6107-6118. [CrossRef]

48. Alunni-Fabbroni, M.; Ronsch, K.; Huber, T.; Cyran, C.C.; Seidensticker, M.; Mayerle, J.; Pech, M.; Basu, B.; Verslype, C.; Benckert, J.; et al. Circulating DNA as prognostic biomarker in patients with advanced hepatocellular carcinoma: A translational exploratory study from the SORAMIC trial. J. Transl. Med. 2019, 17, 328. [CrossRef] [PubMed]

49. Zehir, A.; Benayed, R.; Shah, R.H.; Syed, A.; Middha, S.; Kim, H.R.; Srinivasan, P.; Gao, J.; Chakravarty, D.; Devlin, S.M.; et al. Mutational landscape of metastatic cancer revealed from prospective clinical sequencing of 10,000 patients. Nat. Med. 2017, 23, 703-713. [CrossRef]

50. Qu, C.; Wang, Y.; Wang, P.; Chen, K.; Wang, M.; Zeng, H.; Lu, J.; Song, Q.; Diplas, B.H.; Tan, D.; et al. Detection of early-stage hepatocellular carcinoma in asymptomatic HBsAg-seropositive individuals by liquid biopsy. Proc. Natl. Acad. Sci. USA 2019, 116, 6308-6312. [CrossRef]

51. Brunner, S.F.; Roberts, N.D.; Wylie, L.A.; Moore, L.; Aitken, S.J.; Davies, S.E.; Sanders, M.A.; Ellis, P.; Alder, C.; Hooks, Y.; et al. Somatic mutations and clonal dynamics in healthy and cirrhotic human liver. Nature 2019, 574, 538-542. [CrossRef]

52. Kim, S.K.; Takeda, H.; Takai, A.; Matsumoto, T.; Kakiuchi, N.; Yokoyama, A.; Yoshida, K.; Kaido, T.; Uemoto, S.; Minamiguchi, S.; et al. Comprehensive analysis of genetic aberrations linked to tumorigenesis in regenerative nodules of liver cirrhosis. $J$. Gastroenterol. 2019, 54, 628-640. [CrossRef] [PubMed]

53. Zhu, M.; Lu, T.; Jia, Y.; Luo, X.; Gopal, P.; Li, L.; Odewole, M.; Renteria, V.; Singal, A.G.; Jang, Y.; et al. Somatic Mutations Increase Hepatic Clonal Fitness and Regeneration in Chronic Liver Disease. Cell 2019, 177, 608-621. [CrossRef] [PubMed]

54. Colnot, S.; Decaens, T.; Niwa-Kawakita, M.; Godard, C.; Hamard, G.; Kahn, A.; Giovannini, M.; Perret, C. Liver-targeted disruption of Apc in mice activates beta-catenin signaling and leads to hepatocellular carcinomas. Proc. Natl. Acad. Sci. USA 2004, 101, 17216-17221. [CrossRef] [PubMed]

55. Wang, T.; You, N.; Tao, K.; Wang, X.; Zhao, G.; Xia, N.; Li, N.; Tang, L.; Liu, W.; Dou, K. Notch is the key factor in the process of fetal liver stem/progenitor cells differentiation into hepatocytes. Dev. Growth Differ. 2012, 54, 605-617. [CrossRef]

56. Flynn, D.M.; Nijjar, S.; Hubscher, S.G.; de Goyet Jde, V.; Kelly, D.A.; Strain, A.J.; Crosby, H.A. The role of Notch receptor expression in bile duct development and disease. J. Pathol. 2004, 204, 55-64. [CrossRef]

57. Wang, K.; Zhang, Q.; Li, D.; Ching, K.; Zhang, C.; Zheng, X.; Ozeck, M.; Shi, S.; Li, X.; Wang, H.; et al. PEST domain mutations in Notch receptors comprise an oncogenic driver segment in triple-negative breast cancer sensitive to a gamma-secretase inhibitor. Clin. Cancer Res. 2015, 21, 1487-1496. [CrossRef]

58. Ding, H.; Zhang, X.; Su, Y.; Jia, C.; Dai, C. GNAS promotes inflammation-related hepatocellular carcinoma progression by promoting STAT3 activation. Cell Mol. Biol. Lett. 2020, 25, 8. [CrossRef]

59. Pilati, C.; Zucman-Rossi, J. Mutations leading to constitutive active gp130/JAK1/STAT3 pathway. Cytokine Growth Factor Rev. 2015, 26, 499-506. [CrossRef]

60. Wang, D.; Hu, X.; Long, G.; Xiao, L.; Wang, Z.M.; Zhou, L.D. The clinical value of total plasma cell-free DNA in hepatitis B virus-related hepatocellular carcinoma. Ann. Transl. Med. 2019, 7, 650. [CrossRef]

61. Karlas, T.; Weise, L.; Kuhn, S.; Krenzien, F.; Mehdorn, M.; Petroff, D.; Linder, N.; Schaudinn, A.; Busse, H.; Keim, V.; et al. Correlation of cell-free DNA plasma concentration with severity of non-alcoholic fatty liver disease. J. Transl. Med. 2017, 15, 106. [CrossRef] [PubMed]

62. Nishimoto, S.; Fukuda, D.; Higashikuni, Y.; Tanaka, K.; Hirata, Y.; Murata, C.; Kim-Kaneyama, J.R.; Sato, F.; Bando, M.; Yagi, S.; et al. Obesity-induced DNA released from adipocytes stimulates chronic adipose tissue inflammation and insulin resistance. Sci. Adv. 2016, 2, e1501332. [CrossRef] [PubMed]

63. Yan, L.; Chen, Y.; Zhou, J.; Zhao, H.; Zhang, H.; Wang, G. Diagnostic value of circulating cell-free DNA levels for hepatocellular carcinoma. Int. J. Infect. Dis. 2018, 67, 92-97. [CrossRef] [PubMed]

64. Yoshida, G.J. Emerging role of epithelial-mesenchymal transition in hepatic cancer. J. Exp. Clin. Cancer Res. CR 2016, 35, 141. [CrossRef]

65. Yang, X.D.; Kong, F.E.; Qi, L.; Lin, J.X.; Yan, Q.; Loong, J.H.C.; Xi, S.Y.; Zhao, Y.; Zhang, Y.; Yuan, Y.F.; et al. PARP inhibitor Olaparib overcomes Sorafenib resistance through reshaping the pluripotent transcriptome in hepatocellular carcinoma. Mol. Cancer 2021, 20, 20. [CrossRef]

66. Luk, S.T.; Ng, K.Y.; Zhou, L.; Tong, M.; Wong, T.L.; Yu, H.; Lo, C.M.; Man, K.; Guan, X.Y.; Lee, T.K.; et al. Deficiency in Embryonic Stem Cell Marker Reduced Expression 1 Activates Mitogen-Activated Protein Kinase Kinase 6-Dependent p38 Mitogen-Activated Protein Kinase Signaling to Drive Hepatocarcinogenesis. Hepatology 2020, 72, 183-197. [CrossRef]

67. Qi, L.N.; Xiang, B.D.; Wu, F.X.; Ye, J.Z.; Zhong, J.H.; Wang, Y.Y.; Chen, Y.Y.; Chen, Z.S.; Ma, L.; Chen, J.; et al. Circulating Tumor Cells Undergoing EMT Provide a Metric for Diagnosis and Prognosis of Patients with Hepatocellular Carcinoma. Cancer Res. 2018, 78, 4731-4744. [CrossRef] 
68. Ko, S.; Russell, J.O.; Tian, J.; Gao, C.; Kobayashi, M.; Feng, R.; Yuan, X.; Shao, C.; Ding, H.; Poddar, M.; et al. Hdac1 Regulates Differentiation of Bipotent Liver Progenitor Cells During Regeneration via Sox9b and Cdk8. Gastroenterology 2019, 156, 187202.e14. [CrossRef]

69. Xiao, Q.; Liu, H.; Wang, H.S.; Cao, M.T.; Meng, X.J.; Xiang, Y.L.; Zhang, Y.Q.; Shu, F.; Zhang, Q.G.; Shan, H.; et al. Histone deacetylase inhibitors promote epithelial-mesenchymal transition in Hepatocellular Carcinoma via AMPK-FOXO1-ULK1 signaling axis-mediated autophagy. Theranostics 2020, 10, 10245-10261. [CrossRef]

70. Hong, Y.K.; Li, Y.; Pandit, H.; Li, S.; Pulliam, Z.; Zheng, Q.; Yu, Y.; Martin, R.C.G. Epigenetic modulation enhances immunotherapy for hepatocellular carcinoma. Cell. Immunol. 2019, 336, 66-74. [CrossRef]

71. Xiao, G.; Jin, L.L.; Liu, C.Q.; Wang, Y.C.; Meng, Y.M.; Zhou, Z.G.; Chen, J.; Yu, X.J.; Zhang, Y.J.; Xu, J.; et al. EZH2 negatively regulates PD-L1 expression in hepatocellular carcinoma. J. Immunother. Cancer 2019, 7, 300. [CrossRef]

72. Bugide, S.; Green, M.R.; Wajapeyee, N. Inhibition of Enhancer of zeste homolog 2 (EZH2) induces natural killer cell-mediated eradication of hepatocellular carcinoma cells. Proc. Natl. Acad. Sci. USA 2018, 115, E3509-E3518. [CrossRef]

73. Schulze, K.; Nault, J.C.; Villanueva, A. Genetic profiling of hepatocellular carcinoma using next-generation sequencing. J. Hepatol. 2016, 65, 1031-1042. [CrossRef]

74. Xu, L.X.; He, M.H.; Dai, Z.H.; Yu, J.; Wang, J.G.; Li, X.C.; Jiang, B.B.; Ke, Z.F.; Su, T.H.; Peng, Z.W.; et al. Genomic and transcriptional heterogeneity of multifocal hepatocellular carcinoma. Ann. Oncol. 2019, 30, 990-997. [CrossRef]

75. Cai, Z.; Chen, G.; Zeng, Y.; Dong, X.; Li, Z.; Huang, Y.; Xin, F.; Qiu, L.; Xu, H.; Zhang, W.; et al. Comprehensive Liquid Profiling of Circulating Tumor DNA and Protein Biomarkers in Long-Term Follow-Up Patients with Hepatocellular Carcinoma. Clin. Cancer Res. 2019, 25, 5284-5294. [CrossRef] [PubMed]

76. Fisher-Hoch, S.P.; Rentfro, A.R.; Salinas, J.J.; Perez, A.; Brown, H.S.; Reininger, B.M.; Restrepo, B.I.; Wilson, J.G.; Hossain, M.M.; Rahbar, M.H.; et al. Socioeconomic status and prevalence of obesity and diabetes in a Mexican American community, Cameron County, Texas, 2004-2007. Prev. Chronic Dis. 2010, 7, A53.

77. Wai, C.T.; Greenson, J.K.; Fontana, R.J.; Kalbfleisch, J.D.; Marrero, J.A.; Conjeevaram, H.S.; Lok, A.S. A simple noninvasive index can predict both significant fibrosis and cirrhosis in patients with chronic hepatitis C. Hepatology 2003, 38, 518-526. [CrossRef] [PubMed]

78. American Diabetes, A. Standards of medical care in diabetes-2010. Diabetes Care 2010, 33 (Suppl. S1), S11-S61. [CrossRef]

79. Yamamoto, Y.; Uemura, M.; Nakano, K.; Hayashi, Y.; Wang, C.; Ishizuya, Y.; Kinouchi, T.; Hayashi, T.; Matsuzaki, K.; Jingushi, K.; et al. Increased level and fragmentation of plasma circulating cell-free DNA are diagnostic and prognostic markers for renal cell carcinoma. Oncotarget 2018, 9, 20467-20475. [CrossRef] [PubMed]

80. Chen, K.; Meric-Bernstam, F.; Zhao, H.; Zhang, Q.; Ezzeddine, N.; Tang, L.Y.; Qi, Y.; Mao, Y.; Chen, T.; Chong, Z.; et al. Clinical actionability enhanced through deep targeted sequencing of solid tumors. Clin. Chem. 2015, 61, 544-553. [CrossRef] [PubMed]

81. Li, H.; Durbin, R. Fast and accurate short read alignment with Burrows-Wheeler transform. Bioinformatics 2009, 25, 1754-1760. [CrossRef] [PubMed]

82. DePristo, M.A.; Banks, E.; Poplin, R.; Garimella, K.V.; Maguire, J.R.; Hartl, C.; Philippakis, A.A.; del Angel, G.; Rivas, M.A.; Hanna, M.; et al. A framework for variation discovery and genotyping using next-generation DNA sequencing data. Nat. Genet. 2011, 43, 491-498. [CrossRef] [PubMed]

83. Cibulskis, K.; Lawrence, M.S.; Carter, S.L.; Sivachenko, A.; Jaffe, D.; Sougnez, C.; Gabriel, S.; Meyerson, M.; Lander, E.S.; Getz, G. Sensitive detection of somatic point mutations in impure and heterogeneous cancer samples. Nat. Biotechnol. 2013, 31, 213-219. [CrossRef] [PubMed] 